\title{
Developing and Assessing Elevator Pitches in Capstone Design
}

\section{Dr. Karen C. Davis, University of Cincinnati}

Karen C. Davis is a Professor in the Department of Electrical Engineering and Computing Systems at the University of Cincinnati. Her research interests include database design, query processing and optimization, data warehousing, and engineering/computing education. She has been awarded the ASEE Sharon Keillor Award for Women in Engineering Education, the College of Engineering and Applied Science's Faculty Excellence Award and the Master of Engineering Education Award.

\section{Dr. Fred Richard Beyette Jr., University of Cincinnati}

Dr. Fred R. Beyette Jr. is a Professor in the Department of Electrical Engineering and Computing Systems at the University of Cincinnati. His research interests include point-of-care and wearable technologies for medical diagnostic and health monitoring applications, hardware development of photonic information processing systems and components that bridge the photonic/electronic interface. 


\title{
Developing and Assessing Elevator Pitches in Capstone Design
}

\author{
Karen C. Davis, Ph.D. and Fred R. Beyette, Jr., Ph.D. \\ Electrical Engineering and Computing Systems Department \\ College of Engineering and Applied Science \\ University of Cincinnati \\ Cincinnati, OH 45221-0030 \\ karen.davis@uc.edu
}

\section{Introduction}

Byers et al. suggest that entrepreneurship leads to innovation, which leads to technological advances, which in turn leads to both an enhanced quality of life and the economic benefit of job creation. Students who receive entrepreneurship training are better prepared to be effective team members and work toward solving global problems [1]. One facet of this training is to create and deliver an effective elevator pitch.

In this paper, we utilize one of the e-learning modules developed through the Kern Entrepreneurial Engineering Network (KEEN) and provided by the University of New Haven (UNH), a KEEN partner institution. KEEN promotes engineering education by fostering an entrepreneurial mindset in students: “... beginning with curiosity about our changing world, integrating information from various resources to gain insight, and identifying unexpected opportunities to create value. An engineer equipped with an entrepreneurial mindset is able to create extraordinary value within any type of organization. KEEN schools identify, nurture, and develop entrepreneurially minded engineers who will contribute to our national economic prosperity and secure individual fulfillment through a lifetime of meaningful work." (engineeringunleashed.com)

The UNH KEEN modules are intended to be integrated into engineering and computer science classes at all undergraduate levels. They consist of independent work done via online lessons that include video and readings, along with reflective exercises and quizzes.

At the University of Cincinnati, we deployed the module on developing an elevator pitch in a senior capstone design course. The online module consists of four lessons. The first two lessons introduce the concepts of stakeholders and value propositions, while the latter two introduce developing a pitch and recovering from a failed pitch. We split the four lessons into two halves, two to be completed at the beginning of the semester and the remaining two at the end. The rationale for doing so is that students collect voice-of-customer data at the beginning of the semester to help inform their project proposals and then to evaluate alternate designs around midterm. The first two lessons help the students to broaden their ideas about who their stakeholders could be and to think beyond the technical aspects of the project to address the potential value of the project. At the end of term, they produce an elevator pitch video and conduct a technical design review (TDR). The final lesson about responding to a failed pitch can help students move forward using the critiques from their TDR and video pitch. 
The contributions of this paper include (1) illustration of active learning exercises developed for team-based, in-class activities to support the online content, and (2) development of a rubric to assess the elevator pitch. A survey of rubrics and synthesis of our rubric are given. We discuss experiences deploying the module and in-class activities, the impact on student learning, and results of applying the elevator pitch rubric. We offer several ideas for enhancing delivery of the activities based on our experiences.

\section{Overview of the KEEN Elevator Pitch Modules}

The University of New Haven offers a series of online, independent learning modules [2] covering such topics as

- thinking creatively to drive innovation

- applying systems thinking to complex problems, and

- adapting a business to a changing climate.

The elevator pitch module includes 4 lessons with corresponding learning outcomes, shown in Figure 2.1. Prior to starting the lessons, students self-assess their confidence level with 9 statements related to oral communication and persuasive speaking. After completing the module, students re-assess themselves with the same questions and reflect on changes in their attitudes and perceptions. An example question is

\section{I know I can identify the different groups with an interest in a product.}

The students select a response (mostly, partially, or not at all) for each statement.

Figure 2.1 Lessons and Learning Outcomes [2]

\begin{tabular}{l} 
1. Stakeholders and Their Needs: Identify the value proposition of a product or service from \\
the point of view of a variety of stakeholders. \\
\hline 2. Criteria for a Successful Pitch: Articulate the criteria that yield an effective pitch. \\
\hline 3. Developing Elevator Pitches: Outline a process for developing elevator pitches. \\
\hline $\begin{array}{l}\text { 4. Persisting through Failure: Implement strategies for recovering from an unsuccessful pitch } \\
\text { experience. }\end{array}$
\end{tabular}

The lessons provide an introduction to terminology and concepts associated with elevator pitches. The lessons include opportunities to read about case studies, watch videos, and perform guided reflection on both successful and unsuccessful elevator pitches. The topics in the lessons include:

- identifying stakeholders,

- talking to a non-technical audience,

- creating a value proposition,

- advocating for exigence,

- constructing a pitch, 
- critiquing a pitch,

- and recovering from a bad pitch experience.

A short online quiz is given at the end of each lesson. The intermediate quizzes are not scored for credit, but the final comprehensive quiz is scored. The entire module, including quizzes, is deployed as a Blackboard learning module that can be seamlessly integrated into a course on Blackboard (other learning management system platforms are available as well.)

At the University of Cincinnati in the Electrical Engineering and Computing Systems Department, Electrical and Computer Engineering seniors take a 2-semester senior design course. We give an elevator pitch assignment at the end of the fall term; each team creates a video of their pitch. Previously, to prepare students, we provided some basic guidance about oral presentations and an outline of requirements for an elevator pitch (see Rubric 4 in Figure 4.4). The KEEN elevator pitch module provides comprehensive training in developing an elevator pitch targeted to engineering students. We enthusiastically incorporated this module into our course in Fall 2016. We had 69 students working in 20 teams. Each student completed the module independently. We developed discussion-based team activities for active learning in the classroom (presented in Section 3). To assess the elevator pitches, we developed a rubric synthesized from features found in 12 rubrics for elevator pitches/oral communication publically available on the internet. A discussion of the candidate rubrics is given in Section 4, followed by our proposed rubric in Section 5. Results of applying the rubric and conclusions are offered in Section 6.

\section{In-class Activities}

In order to reinforce concepts from the KEEN elevator pitch module, our first in-class activity was to re-watch Timothy Prestero's TED talk video on failed and successful inventions [3] together and then discuss the steps to developing a value proposition. These steps are (1) identifying stakeholders, (2) identifying the problem to be solved for each stakeholder, (3) determining the specific contribution or need fulfilled for that stakeholder, and (4) comparing the proposed solution to other existing options. We created the chart shown in Figure 3.1 to be completed by each team in class. This activity served as a warm-up before starting preparation for each team's individual pitch. At this point, communication between team members is at a beginning level, as is use of the terminology and concepts necessary for creating a value proposition. Volunteers from different teams shared their answers after a few minutes of teambased discussion and completion of the worksheet. 
Figure 3.1 Initial In-class Activity

\begin{tabular}{|c|c|c|c|}
\hline \multicolumn{4}{|c|}{ Create Value Propositions: Firefly Phototherapy Device } \\
\hline 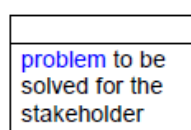 & manufacturer & clinic director & parent \\
\hline 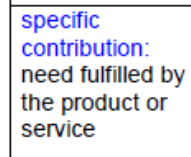 & & & \\
\hline \begin{tabular}{|l} 
comparison to \\
existing to \\
solutions or \\
other options
\end{tabular} & & & \\
\hline
\end{tabular}

The second activity focused on the team's pre-preparation for an elevator pitch. At this early point in the term, the teams were clarifying their project topics and initiating collection of voiceof-customer data. They were not yet ready for developing a full pitch, and they had not yet completed the second half of the KEEN elevator pitch module. The learning objective of this activity was to use elevator pitch terminology and capture preliminary ideas that would lead to an elevator pitch at the end of the term. Teams began by discussing an "argument for exigence," or identifying an urgent need to be met by the project. The project was then described in nontechnical terms, an outcome which is sometimes difficult for engineering students to master. In this exercise, they had to explain the project to themselves and then to their nearby classmates. This is an intermediate-level oral communication activity since it involves expressing concepts that may be clear in the mind of the speaker but which require some reflection to express them to an audience unfamiliar with the specific project topic. The teams then developed a value proposition and reflected on what they would ask for in their pitch. The worksheet is given in Figure 3.2. 
Figure 3.2 Brainstorming for Elevator Pitch Preparation

\begin{tabular}{|l|l|}
\hline \multicolumn{2}{|c|}{ Outlining Your Pitch } \\
\hline \begin{tabular}{|l||}
\hline $\begin{array}{l}\text { argument for } \\
\text { exigence }\end{array}$ \\
\end{tabular} \\
\hline $\begin{array}{l}\text { non-technical } \\
\text { description }\end{array}$ & \\
\hline $\begin{array}{l}\text { value } \\
\text { proposition }\end{array}$ & \\
\hline ask/request & \\
\hline
\end{tabular}

Our experience with the activities is that the students were not as prepared to participate in discussions as we would have expected. In the future, a review of the terminology and concepts from the online lessons should be conducted by the professors in class, followed by discussion of a worked example to illustrate expectations for what they should be able to do with respect to their own project.

\section{Survey of Online Elevator Pitch Rubrics}

An online search using the term "elevator pitch rubric" yielded many results. The rubrics considered here are a representative sample where each has some distinctive and useful features that can be synthesized into an elevator pitch rubric that aligns both with the KEEN elevator pitch module and expectations for an engineering senior design project video. The rubrics are numbered and the institution or author (where known) are listed in Table 1. The URLs for the rubrics are included as well. Hereafter, the rubrics are referred to by the number given in the leftmost column. 
Table 4.1. Sources for Rubrics (accessed 7/27/2016)

\begin{tabular}{|c|c|}
\hline number & institution and URL \\
\hline 1 & $\begin{array}{l}\text { Santa Ana Unified School District } \\
\text { www.sausd.us/cms/lib5/CA01000471/Centricity/Domain/494/ElevatorOK_14.pd } \\
\text { f }\end{array}$ \\
\hline 2 & $\begin{array}{l}\text { University of Cincinnati -- Business } \\
\text { https://business.uc.edu/content/dam/business/centers/enterpreneurship/docs/2016 } \\
\text { docs/Elevator\%20Pitch\%20Evaluation\%20Sheet.pdf }\end{array}$ \\
\hline 3 & $\begin{array}{l}\text { author: jabowen } \\
\text { http://www.rcampus.com/rubricshowc.cfm?code=W5CCX7\&sp=true }\end{array}$ \\
\hline 4 & $\begin{array}{l}\text { University of Cincinnati -- EECS } \\
\text { created by the authors, used in previous academic terms }\end{array}$ \\
\hline 5 & 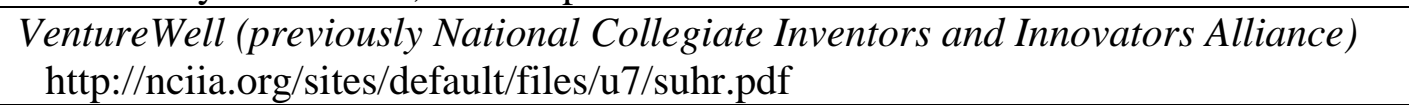 \\
\hline 6 & $\begin{array}{l}\text { Wichita State University } \\
\text { http://webs.wichita.edu/depttools/depttoolsmemberfiles/ace/ACE\%20Epitch\%20 } \\
\text { Score\%20Sheet.pdf }\end{array}$ \\
\hline 7 & $\begin{array}{l}\text { University of Wisconsin-Platteville } \\
\text { https://www.uwplatt.edu/files/entrepreneurship/Elevator\%20Pitch_Guidelines\%2 } \\
\text { 0\&\%20Rubric.pdf }\end{array}$ \\
\hline 8 & $\begin{array}{l}\text { Baker College Business Connection } \\
\text { http://guides.baker.edu/BCBC/elevatorpitch }\end{array}$ \\
\hline 9 & $\begin{array}{l}\text { Project Lead the Way } \\
\text { https://ltlatnd.wordpress.com/2015/12/15/elevator-pitches/ }\end{array}$ \\
\hline 10 & $\begin{array}{l}\text { TES Resources. For teachers, by teachers. } \\
\text { https://driftlessregioninnovationevent.wikispaces.com/file/view/Elevator+Pitch+2 } \\
\text { 011.doc }\end{array}$ \\
\hline 11 & $\begin{array}{l}\text { University of Northern Colorado } \\
\text { http://mcb.unco.edu/Events/networkingnight/ElevatorPitch/ }\end{array}$ \\
\hline 12 & $\begin{array}{l}\text { AAC\&U VALUE Rubric for Oral Communication } \\
\text { https://www.aacu.org/value/rubrics/oral-communication }\end{array}$ \\
\hline
\end{tabular}

Each rubric is discussed in a figure below. The figures are annotated with markup such as gold stars (indicating a new idea to be considered for incorporation into the synthesized rubric), red lines (ideas that are not suitable for our assignment and will not be further considered), and light blue pop-up comments that indicate observations about the rubric. A text box below each rubric summarizes the applicability of the rubric for our synthesis effort.

In terms of topicality, Rubrics 1-5 are the most relevant. None are suitable as is; they all have text that could be leveraged, but the categories could be combined and rewritten. Rubrics 6-8 are topical but do not include sufficient (if any) descriptive text of how to apply the categories for evaluation. The remaining ones, Rubrics 9-12, are less specific to an elevator pitch (as developed in the KEEN elevator pitch module) and more focused on aspects of delivery. Each rubric contributed in some way to the synthesized rubric given in Section 5. 


\section{Figure 4.1 Rubric 1}

\begin{tabular}{|c|c|c|c|c|}
\hline & & & & $\begin{array}{l}\text { almost every p } \\
\text { could be impro } \\
\text { in some way }\end{array}$ \\
\hline \multirow{2}{*}{ RATINGS: } & Unacceptable & Requires Improvement & Good & Superior \\
\hline & $0-2$ & $3-5$ & $6-8$ & $9-10$ \\
\hline \multicolumn{5}{|l|}{ CONTENT } \\
\hline $\begin{array}{l}\text { ClNTRO/HOOK } \\
\text { and product or what the company } \\
\text { does }\end{array}$ & $\begin{array}{l}\text { You forgot your } \\
\text { company name or } \\
\text { what the company }\end{array}$ & $\begin{array}{l}\text { You identified your } \\
\text { company and there } \\
\text { is some attempt to }\end{array}$ & $\begin{array}{l}\text { You introduced your } \\
\text { company in a way } \\
\text { that showed some }\end{array}$ & $\begin{array}{l}\text { OMG! I'm hooked!!! } \\
\text { You were honest, } \\
\text { but used a twist and }\end{array}$ \\
\hline \multirow[b]{2}{*}{$\begin{array}{l}\text { NEED/OPPORTUNITY } \\
\text { Explain the problem facing your } \\
\text { customers or the opportunity } \\
\text { available to your company. Why } \\
\text { and by whom is this product/service } \\
\text { needed? }\end{array}$} & \multirow{2}{*}{\multicolumn{3}{|c|}{\begin{tabular}{l|l|l|}
$\begin{array}{l}\text { You are ung } \\
\text { you solve a } \\
\text { or can seize }\end{array}$ & \multicolumn{2}{|c|}{$\begin{array}{l}\text { Company } \\
\text { opportunity. You }\end{array}$} \\
$\begin{array}{l}\text { just have a product } \\
\text { to sell. You aren't } \\
\text { sure you need it. }\end{array}$ & $\begin{array}{l}\text { really don t know } \\
\text { who your customers } \\
\text { are and why they } \\
\text { need your product. }\end{array}$ & $\begin{array}{l}\text { I understand the } \\
\text { problem/opportunity } \\
\text { and I am clear who } \\
\text { your customers are } \\
\text { but I'm not sure why } \\
\text { they need your } \\
\text { product. }\end{array}$
\end{tabular}}} & \\
\hline & & & & $\begin{array}{l}\text { what your product } \\
\text { will do for your } \\
\text { customers AND it } \\
\text { immediately seems } \\
\text { important to me. }\end{array}$ \\
\hline $\begin{array}{l}\text { BUSINESS SOLUTION } \\
\text { Explain how your company. } \\
\text { technology, or invention will solve } \\
\text { this problem or meet this } \\
\text { opportunity. }\end{array}$ & What problem? & \begin{tabular}{|l|} 
I have only a vague \\
understanding of \\
how your company \\
will solve this \\
problem or take \\
advantage of this \\
opportunity.
\end{tabular} & $\begin{array}{l}\text { You've given me a } \\
\text { completed } \\
\text { explanation of how } \\
\text { your business solves } \\
\text { the problem or takes } \\
\text { advantage of the } \\
\text { opportunity. }\end{array}$ & $\begin{array}{l}\text { You've given a } \\
\text { detailed } \& \text { extensive } \\
\text { explanation of how } \\
\text { business solves a } \\
\text { problem or takes } \\
\text { advantage of an } \\
\text { opportunity. I'm in! }\end{array}$ \\
\hline \multirow{2}{*}{$\begin{array}{l}\text { REVENUE MODEL } \\
\text { Explain how you will earn your } \\
\text { revenue and from whom. }\end{array}$} & $\begin{array}{l}\text { You don't know who } \\
\text { your market is and }\end{array}$ & $\begin{array}{l}\text { I have a vague } \\
\text { understanding of }\end{array}$ & $\begin{array}{l}\text { You've made it clear } \\
\text { how you will earn }\end{array}$ & $\begin{array}{l}\text { You have an } \\
\text { awesome revenue }\end{array}$ \\
\hline & \multicolumn{3}{|c|}{ 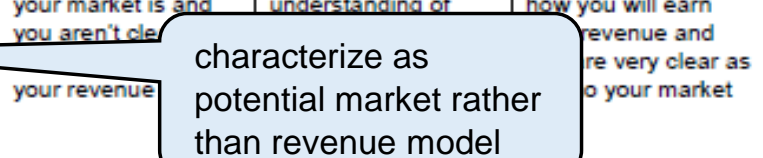 } & $\begin{array}{l}\text { model! Why didn't I } \\
\text { think of that? } \\
\text { You've convinced } \\
\text { me that it's perfect } \\
\text { for your market! }\end{array}$ \\
\hline COMPETITIVE ADVANTAGE & $\begin{array}{l}\text { Competitors? } \\
\text { your world you think } \\
\text { you have no } \\
\text { competitors! }\end{array}$ & \begin{tabular}{|l|} 
competition but you \\
have not presented \\
any evidence that \\
you have an \\
advantage over \\
them. \\
\end{tabular} & $\begin{array}{l}\text { und have a clear } \\
\text { your competition and } \\
\text { have presented } \\
\text { some evidence of } \\
\text { your advantage. }\end{array}$ & $\begin{array}{l}\text { I'm impressed! You } \\
\text { have exceptional } \\
\text { understanding of } \\
\text { the competition and } \\
\text { you have } \\
\text { compelling evidence } \\
\text { of your advantage. }\end{array}$ \\
\hline \multirow{3}{*}{$\begin{array}{l}\text { WRAP UP } \\
\text { You have made a compelling case } \\
\text { and have asked me for a follow up } \\
\text { meeting. }\end{array}$} & $\begin{array}{l}\text { You have not } \\
\text { defined the }\end{array}$ & $\begin{array}{l}\text { You have defined } \\
\text { the opportunity but }\end{array}$ & \multirow{3}{*}{$\begin{array}{l}\text { You have clearly } \\
\text { and concisely } \\
\text { defined the } \\
\text { opportunity but I see } \\
\text { no compelling } \\
\text { reason to support } \\
\text { you and you haven't } \\
\text { ask for another } \\
\text { meeting to tell me } \\
\text { more }\end{array}$} & \multirow{3}{*}{$\begin{array}{l}\text { I am fully engaged } \\
\text { and I want a follow } \\
\text { up meeting - you } \\
\text { have clearly and } \\
\text { concisely defined } \\
\text { the opportunity and } \\
\text { your passion for this } \\
\text { company is clear. } \\
\text { How soon can we } \\
\text { meet?! } \\
\end{array}$} \\
\hline & $\begin{array}{l}\text { rename a } \\
\text { does not } r \\
\text { up meetin }\end{array}$ & $\begin{array}{l}\text { CLOSING; } \\
\text { heed a follow- } \\
\text { g }\end{array}$ & & \\
\hline \multirow{2}{*}{\multicolumn{5}{|c|}{ DELIVERY }} \\
\hline & & & & \\
\hline $\begin{array}{l}\text { ENERGY and CONFIDENCE } \\
\text { Natural, enthusiastic, speech with } \\
\text { clarity, proper volume and good flow }\end{array}$ & $\begin{array}{l}\text { No eye contact, } \\
\text { voice inaudible, you } \\
\text { lacked confidence or } \\
\text { enthusiasm. }\end{array}$ & \begin{tabular}{|l|} 
Some eye contact, \\
voice barely audible, \\
some enthusiasm but \\
pitch didn't flow.
\end{tabular} & $\begin{array}{l}\text { Good eye contact, } \\
\text { clear voice, } \\
\text { enthusiastic, but you } \\
\text { might tweak the flow }\end{array}$ & $\begin{array}{l}\text { Great eye contact, } \\
\text { clear voice, flow } \\
\text { was perfect, and } \\
\text { your enthusiasm is }\end{array}$ \\
\hline \multicolumn{5}{|c|}{$\begin{array}{l}\text { - } \quad \text { good categories; use the content and delivery meta-categories } \\
\text { need to rewrite the text to better align with the KEEN module and our } \\
\text { expectations for our projects } \\
\text { - } \quad \text { eliminate use of both first and second person and colloquial expressions }\end{array}$} \\
\hline
\end{tabular}




\section{Figure 4.2 Rubric 2}

\begin{tabular}{|c|c|c|c|c|c|}
\hline & 5 & 4 & 3 & 2 & 1 \\
\hline Time & $1: 30-2: 00$ & $1: 20-1: 30,2: 00-2: 10$ & $1: 10-1: 20,2: 10-2: 20$ & $1: 00-1: 10,2: 20-2: 30$ & $<1: 00,>2: 30$ \\
\hline \multirow[t]{2}{*}{ Overall Presentation } & $\begin{array}{l}\text { Polished, poised, } \\
\text { and captivating. }\end{array}$ & $\begin{array}{l}\text { Well-rehearsed, and } \\
\text { interesting with few to }\end{array}$ & $\begin{array}{l}\text { Slight nervousness or } \\
\text { uncertainty, }\end{array}$ & $\begin{array}{l}\text { Moderate nervousness } \\
\text { or uncertainty, }\end{array}$ & $\begin{array}{l}\text { Pronounced } \\
\text { nervousness and }\end{array}$ \\
\hline & \multicolumn{2}{|c|}{$\begin{array}{ll}\text { visuaram } & \begin{array}{l}\text { add delivery } \\
\text { categories }\end{array}\end{array}$} & $\begin{array}{l}\text { somewhat confusing, } \\
\text { fair visual aids }\end{array}$ & $\begin{array}{l}\text { presentation. Used low } \\
\text { quality visual aids. }\end{array}$ & $\begin{array}{l}\text { serious logic gaps in } \\
\text { presentation. Used } \\
\text { very low quality visual } \\
\text { aids, }\end{array}$ \\
\hline \multirow[t]{2}{*}{ Pain/problem } & $\begin{array}{l}\text { Problem identified } \\
\text { is serious and not }\end{array}$ & $\begin{array}{l}\text { Problem identified is } \\
\text { serious and could be }\end{array}$ & $\begin{array}{l}\text { Problem identified is } \\
\text { significant and current }\end{array}$ & $\begin{array}{l}\text { Problem being } \\
\text { addressed is minor and }\end{array}$ & $\begin{array}{l}\text { There is no problem } \\
\text { here. Shared by a very }\end{array}$ \\
\hline & \multicolumn{2}{|c|}{ very la $\underbrace{\text { need/opportunity }}_{\text {large market. }}$} & $\begin{array}{l}\text { solutions are } \\
\text { adequate. Shared by } \\
\text { moderately sized } \\
\text { target market. }\end{array}$ & $\begin{array}{l}\text { current solutions are } \\
\text { very adequate, Shared } \\
\text { by a small target. }\end{array}$ & \\
\hline Premise/product/plan & $\begin{array}{l}\text { Solution to problem } \\
\text { is amazing, game } \\
\text { changing, or game } \\
\text { creating. }\end{array}$ & $\begin{array}{l}\text { Solution is significantly } \\
\text { better than existing } \\
\text { alternatives. }\end{array}$ & $\begin{array}{l}\text { Solution is interesting, } \\
\text { and has some } \\
\text { adequate benefits over } \\
\text { existing alternatives. }\end{array}$ & $\begin{array}{l}\text { Solution is not very } \\
\text { novel and only } \\
\text { marginally different } \\
\text { from existing } \\
\text { alternatives. }\end{array}$ & $\begin{array}{l}\text { Solution has not novel } \\
\text { and has no competitive } \\
\text { advantage in the } \\
\text { market place }\end{array}$ \\
\hline People/Team & $\begin{array}{l}\text { These are the only } \\
\text { people to do this! }\end{array}$ & $\begin{array}{l}\text { This team has } \\
\text { advantages that would } \\
\text { be difficult to duplicate }\end{array}$ & $\begin{array}{l}\text { This is a great team for } \\
\text { this idea, but some } \\
\text { others could do as } \\
\text { well, or this team lacks } \\
\text { one or more critical } \\
\text { pieces }\end{array}$ & $\begin{array}{l}\text { This team has multiple } \\
\text { issues such as gaps in } \\
\text { experience and } \\
\text { expertise }\end{array}$ & $\begin{array}{l}\text { This team will be } \\
\text { unable to realize this } \\
\text { idea }\end{array}$ \\
\hline Proof/Credibility & $\begin{array}{ll}\text { Relievahle mar } & \mathrm{co} \\
\text { testing,pror } & \mathrm{pe} \\
\text { working proto } & \mathrm{pe}\end{array}$ & $\begin{array}{l}\text { nbine with } \\
\text { ople/team }\end{array}$ & $\begin{array}{l}\text { Convenience type } \\
\text { market research; } \\
\text { unsubstantiated } \\
\text { testimonials } \\
\end{array}$ & $\begin{array}{l}\text { Team member's } \\
\text { opinions; research you } \\
\text { doubt or don't believe }\end{array}$ & $\begin{array}{l}\text { No proof whatsoever } \\
\text { that this idea will work }\end{array}$ \\
\hline Purpose/Profit Potential & $\begin{array}{l}\text { Huge profit } \\
\text { potential; tempted } \\
\text { to invest own } \\
\text { money }\end{array}$ & $\begin{array}{l}\text { Taea seems Tाke it could } \\
\text { be a big winner in the } \\
\text { marketplace }\end{array}$ & $\begin{array}{l}\text { This idea could be } \\
\text { successful and lead to } \\
\text { a growing company or } \\
\text { highly successful } \\
\text { lifestyle business }\end{array}$ & $\begin{array}{l}\text { This idea could provide } \\
\text { partial income for the } \\
\text { team members }\end{array}$ & $\begin{array}{l}\text { This idea could not } \\
\text { provide an income for } \\
\text { the team members, or } \\
\text { will not provide a } \\
\text { profit at all }\end{array}$ \\
\hline
\end{tabular}

\section{- consider leveraging the text with some rewrites}




\section{Figure 4.3 Rubric 3}

\begin{tabular}{|c|c|c|c|c|}
\hline \multicolumn{5}{|l|}{$\begin{array}{l}\text { Elevator Pitch } \\
\text { Enter rubric description }\end{array}$} \\
\hline & $\begin{array}{l}\text { Poor } \\
0 \text { pts }\end{array}$ & $\begin{array}{l}\text { Fair } \\
35 \text { pts }\end{array}$ & $\begin{array}{l}\text { Good } \\
90 \text { pts }\end{array}$ & $\begin{array}{l}\text { Great } \\
100 \text { pts }\end{array}$ \\
\hline $\begin{array}{l}\text { Intro/Hook } \\
10 \% \text { Enter description }\end{array}$ & $\begin{array}{l}\text { Poor } \\
\text { You just started in with info } \\
\text { or forgot your name. }\end{array}$ & $\begin{array}{l}\text { Fair } \\
\text { You said your name and } \\
\text { there is some attempt to } \\
\text { create an intro, but I am not } \\
\text { hooked. There was nothing } \\
\text { unique or creative about the } \\
\text { intro, or it was hokey or } \\
\text { gimmicky. }\end{array}$ & $\begin{array}{l}\text { Good } \\
\text { You used a sentence to } \\
\text { introduce yourself in a way } \\
\text { that showed some } \\
\text { relevance and there was } \\
\text { some creativity and it was } \\
\text { memorable in some way. }\end{array}$ & $\begin{array}{l}\text { Great } \\
\text { OMG! I'm hooked!!! You } \\
\text { were honest, but used a } \\
\text { twist and now I want to } \\
\text { know more. }\end{array}$ \\
\hline $\begin{array}{l}\text { Aspirations/Goals } \\
15 \% \text { Enter description }\end{array}$ & $\begin{array}{l}\text { Poor } \\
\text { I get no sense of what you } \\
\text { want to do with your art. }\end{array}$ & $\begin{array}{l}\text { Fair } \\
\text { Your aspirations are either } \\
\text { too narrow or not relevant } \\
\text { to most audiences. }\end{array}$ & $\begin{array}{l}\text { Good } \\
\text { Grandma can understand } \\
\text { your goals and so can I. } \\
\text { They are mostly relevant. } \\
\text { They seem to make sense } \\
\text { for you. }\end{array}$ & $\begin{array}{l}\text { Great } \\
\text { Your goals immediately } \\
\text { seem important to me too. }\end{array}$ \\
\hline $\begin{array}{l}\text { Because/Why } \\
30 \% \text { Enter description }\end{array}$ & $\begin{array}{l}\text { Poor } \\
\text { You made no attempt to tell } \\
\text { me why your goals matter } \\
\text { to anyone but you. }\end{array}$ & $\begin{array}{l}\text { Fair } \\
\text { I get some sense of who } \\
\text { you are and why your art } \\
\text { matters to you, but not } \\
\text { much understanding about } \\
\text { what it does for others. }\end{array}$ & $\begin{array}{l}\text { Good } \\
\text { You have told me what what } \\
\text { your art will do with, } \\
\text { through or for others. }\end{array}$ & $\begin{array}{l}\text { Great } \\
\text { You have told me what what } \\
\text { your art will do with, } \\
\text { through or for others AND it } \\
\text { immediately seems } \\
\text { important to me }\end{array}$ \\
\hline $\begin{array}{l}\text { Realistic } \\
15 \% \text { Are your goals } \\
\text { realistic? }\end{array}$ & $\begin{array}{c}\text { Poor } \\
\text { You are going to bring world } \\
\text { peace to millions while } \\
\text { mf } \\
\text { evidence for suita } \\
\text { to address goals } \\
\text { achieve success }\end{array}$ & 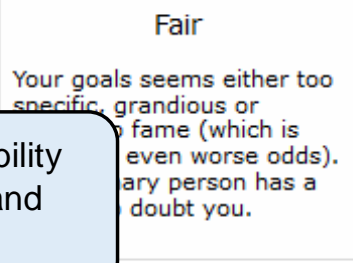 & $\begin{array}{l}\text { Good } \\
\text { I think you have mostly } \\
\text { realistic expectations, but } \\
\text { you have not presented me } \\
\text { with any evidene that you } \\
\text { are so much better suited to } \\
\text { reach your goals than the } \\
\text { next person. }\end{array}$ & $\begin{array}{l}\text { Great } \\
\text { I'm impressed, but think if } \\
\text { anyone can do it, you can, } \\
\text { and that you are realistic in } \\
\text { the difficulty and complexity } \\
\text { of the challenge }\end{array}$ \\
\hline $\begin{array}{l}\text { Closing/Invitation } \\
10 \% \text { Is there a way to } \\
\text { continue this conversation? }\end{array}$ & $\begin{array}{l}\text { You forgot to ask me for } \\
\text { anything. }\end{array}$ & $\begin{array}{l}\text { Fair } \\
\text { You asked me for a } \\
\text { business card, but it } \\
\text { seemed less than } \\
\text { compelling. }\end{array}$ & $\begin{array}{l}\text { Good } \\
\text { You offered a card (the best } \\
\text { way to get one) and invited } \\
\text { me to continue. Perhaps } \\
\text { you asked for my advice } \\
\text { too }\end{array}$ & $\begin{array}{l}\text { Great } \\
\text { You invited me to continue } \\
\text { our conversation and I want } \\
\text { to continue because you left } \\
\text { me with a next question. }\end{array}$ \\
\hline $\begin{array}{l}\text { Grammar/Clarity } \\
\mathbf{1 0} \% \text { and Organization! Is } \\
\text { this the best way to say } \\
\text { this? }\end{array}$ & $\begin{array}{l}\text { Poor } \\
\text { Huh? I can't understand } \\
\text { what you are saying. }\end{array}$ & $\begin{array}{l}\text { Fair } \\
\text { You did not get the basic } \\
\text { structure right and there are } \\
\text { al mistakes. }\end{array}$ & $\begin{array}{l}\text { Good } \\
\text { Clear and correct, but you } \\
\text { might tweak the order to } \\
\text { get more of a twist. }\end{array}$ & $\begin{array}{l}\text { Great } \\
\text { Clear and correct and well } \\
\text { organized }\end{array}$ \\
\hline $\begin{array}{l}\text { Length } \\
10 \%\end{array}$ & $\begin{array}{l}\text { combine gramm } \\
\text { clarity, and lengt } \\
\text { aspects of delive }\end{array}$ & $\begin{array}{l}\text { Fair } \\
\text { be } 25 \% \text { shorter }\end{array}$ & $\begin{array}{l}\text { Good } \\
\text { Very good, but you need to } \\
\text { try and get it down to } 5 \\
\text { sentences or } 60 \text { seconds, or } \\
\text { longer than two sentences. }\end{array}$ & $\begin{array}{l}\text { Great } \\
4-6 \text { sentences and } 60 \\
\text { seconds. You rock! }\end{array}$ \\
\hline
\end{tabular}

- $\quad$ adjust the weights

- replace the descriptive text with text aligned to technical elevator pitch

- reverse order from weak to strong, similar to VALUE rubric (Rubric 12 here) 


\section{Figure 4.4 Rubric 4}

Problem description: Based on the problem clarification work you did early in the semester, provide a detailed description of the problem your project addresses and why the problem is important to solve. Comments:

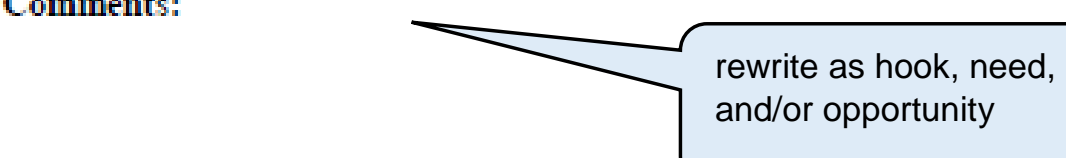

Who needs it/who buys it: Who benefits from your project! wno wornu use your project solution? Who would buy it (if different from who uses it)?

Comments:

Size of market/user base: How many potential users/buyers exist for your project? Comments:

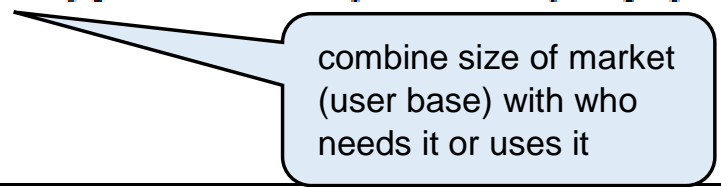

Competitors/competitive advantage: Are there competing products/projects out there? How does your approach provide a competitive advantage?

Comments:

What is the expected cost for your project: How much will it cost you to build a prototype? How much do you think you could sell the product for? Why?

Comments:

Presentation Style: Was the presentation clear? Did all team members participate? Was the team enthusiastic about the project?

Comments:

Creativity: Surprise me! Make me laugh. Make me want your project. Somehow give me more than just the numbers.

Comments:

combine style and creativity into aspects of delivery

- $\quad$ add scoring categories

- adjust the weights 


\section{Figure 4.5 Rubric 5}

\begin{tabular}{|l|}
\hline \multicolumn{1}{|c|}{ Criteria } \\
\hline $\begin{array}{l}\text { Market Opportunity? Was } \\
\text { they are solving? Was the size of their opportunity clear and quantified? Was the target customer } \\
\text { of their opportunity identified? }\end{array}$ \\
\hline $\begin{array}{l}\text { Why you? Was their competitive advantage clear? Did they express why their management team } \\
\text { is qualified for their opportunity? }\end{array}$ \\
\hline $\begin{array}{l}\text { Impact? Did they explicitly request some form of support (time, expertise or money)? Were they } \\
\text { memorable? Could you repeat the main ideas of their venture? Was it 30-seconds or less? }\end{array}$ \\
\hline $\begin{array}{l}\text { Good Story? Did their pitch arouse your attention and hold it? Would you share their story with } \\
\text { others? }\end{array}$ \\
\hline Compelling? Was their argument persuasive and forceful? Did you learn something? \\
\hline
\end{tabular}

- leverage the text for content details

- uses KEEN module terminology: value proposition 


\section{Figure 4.6 Rubric 6}

\section{Content}

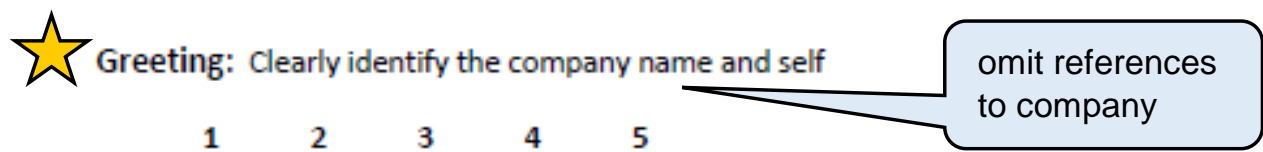

Need: Explain the problem facing your customers. Who are your competitors? Why do they fall short?

$\begin{array}{lllll}1 & 2 & 3 & 4 & 5\end{array}$

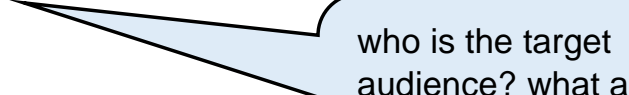

Solution: Explain how your company, technology, or invention would solve this probl audience? what are alternatives and their $\begin{array}{lllll}1 & 2 & 3 & 4 & 5\end{array}$ shortcomings?

Business Model: How do you make money?(Sell to a whole seller? License and receive royalties? Other?)

1<smiles>C1CCCCC1</smiles><smiles>[Z]C1CC1</smiles>

\section{4}

5

Exit: How will you pay back your investor and make them profit (At least double their money, more likely 5-10 times their money)?

The Ask: How much money do you need and what will you do with it?

12
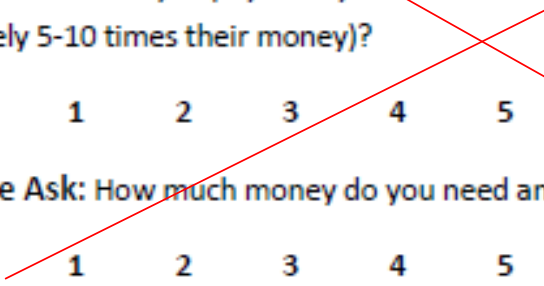

\section{$\sum$ Delivery}

Energy/Confidence: Natural, enthusiastic, and speech with a good flow

\section{$\begin{array}{lllll}1 & 2 & 3 & 4 & 5\end{array}$}

Voice/speech: Clarity of speech, proper volume, rate of speech

$\begin{array}{lllll}1 & 2 & 3 & 4 & 5\end{array}$

Over time limit ( 90 Seconds): $\quad$ Yes No (If yes then subtract 15 points)

leave the length open
(too short or too long)
to make the rubric
more general

- $\quad$ add descriptions for the scores 


\section{Figure 4.7 Rubric 7}

1. What is the assumed problem, need, and/or opportunity that your product, business, or nonprofit addresses?

2. What is your idea?

3. Who do you assume to be your target customer(s)?

4. Where or how did the idea come to you?

What is your next step(s)?

What do you need help with to accomplish your next step(s)?

add next steps and resources

\begin{tabular}{|l|c|}
\hline & Points \\
\hline Problem, need, or opportunity that their product, business, or non-profit will address & $/ 10$ \\
\hline Explanation of their idea & $/ 10$ \\
\hline Target customer(s) & $/ 10$ \\
\hline Where-or how they came up with the idea- & $/ 10$ \\
\hline Their next step(s)? & $/ 10$ \\
\hline What they need help with to accomplish the next step(s) & $/ 10$ \\
\hline & \\
\hline Have they made a compelling case? Have they piqued your interest ko help them & $/ 10$ \\
\hline Presentation (delivery, kept your interest, explained the idea well) & $/ 10$ \\
\hline Questions and Answers with judges & $/ 10$ \\
\hline For putting themselves out there and doing it & 110 \\
\hline & TOTAL \\
& $/ 100$ \\
\hline
\end{tabular}

- leverage ideas in the text

Figure 4.8 Rubric 8

Hook (Did intro grab your attention?)
Unique Features/Benefits Clearly Defined
Market Well Defined
$\begin{aligned} & \text { Presentation Style } \\ & \text { (professional appearance, conciseness of message, } \\ & \text { persuasiveness, quality of delivery) }\end{aligned}$




\section{Figure 4.9 Rubric 9}

\begin{tabular}{|c|c|c|c|c|c|c|}
\hline Elements & Weight & 5 Points & 4 Points & 3 Points & 2 Points & 1-0 Points \\
\hline Content & & $\begin{array}{l}\text { The information } \\
\text { included is accurate } \\
\text { and completely } \\
\text { addresses each } \\
\text { component of the } \\
\text { assigned topic or } \\
\text { research question. }\end{array}$ & $\begin{array}{l}\text { The information } \\
\text { included adequately } \\
\text { addresses each } \\
\text { component of the } \\
\text { assigned topic or } \\
\text { research question. }\end{array}$ & $\begin{array}{l}\text { The information } \\
\text { included inadequately } \\
\text { addresses the } \\
\text { assigned topic or } \\
\text { research question. } \\
\text { The information } \\
\text { included is sometimes } \\
\text { inaccurate. }\end{array}$ & $\begin{array}{l}\text { The information } \\
\text { included does not } \\
\text { address the } \\
\text { assigned topic or } \\
\text { research. }\end{array}$ & $\begin{array}{l}\text { There is no } \\
\text { evidence of } \\
\text { accurate content } \\
\text { information. }\end{array}$ \\
\hline Delivery & & $\begin{array}{l}\text { The presenter } \\
\text { effectively and } \\
\text { creatively delivers the } \\
\text { information while } \\
\text { staying on topic. The } \\
\text { presenter appears } \\
\text { relaxed and self- } \\
\text { confident. Body } \\
\text { language, voice } \\
\text { modulation, and eye } \\
\text { contact are effectively } \\
\text { used. }\end{array}$ & $\begin{array}{l}\text { The presenter } \\
\text { adequately delivers } \\
\text { the information while } \\
\text { staying on topic. The } \\
\text { presenter appears } \\
\text { relaxed and self- } \\
\text { confident. Body } \\
\text { language, voice } \\
\text { modulation, and eye } \\
\text { contact are mostly } \\
\text { appropriate. }\end{array}$ & $\begin{array}{l}\text { The presenter delivers } \\
\text { the information but } \\
\text { does not stay on topic. } \\
\text { The presenter } \\
\text { appears tense or } \\
\text { nervous. Body } \\
\text { language, voice } \\
\text { modulation, and eye } \\
\text { contact are } \\
\text { inappropriate or } \\
\text { lacking. }\end{array}$ & $\begin{array}{l}\text { The presenter omits } \\
\text { important } \\
\text { information and does } \\
\text { not stay on topic. } \\
\text { The presenter } \\
\text { appears tense or } \\
\text { nervous. Body } \\
\text { language, voice } \\
\text { modulation, and eye } \\
\text { contact are } \\
\text { inappropriate or } \\
\text { lacking. }\end{array}$ & $\begin{array}{l}\text { The presenter } \\
\text { does not } \\
\text { effectively deliver } \\
\text { the necessary } \\
\text { information. }\end{array}$ \\
\hline Organization & & $\begin{array}{l}\text { The presentation } \\
\text { content has been } \\
\text { organized using a } \\
\text { logical sequence. The } \\
\text { presentation is } \\
\text { engaging and } \\
\text { effective. }\end{array}$ & $\begin{array}{l}\text { The presentation } \\
\text { content has been } \\
\text { mostly organized } \\
\text { using a logical } \\
\text { sequence, but some } \\
\text { flaws exist. The } \\
\text { presentation is } \\
\text { adequate. }\end{array}$ & $\begin{array}{l}\text { The presentation } \\
\text { content has been } \\
\text { organized using a } \\
\text { somewhat logical } \\
\text { sequence. The } \\
\text { presentation is } \\
\text { sometimes confusing. }\end{array}$ & $\begin{array}{l}\text { The presentation } \\
\text { content is } \\
\text { disorganized, } \\
\text { unclear, or } \\
\text { confusing. The } \\
\text { presentation is not } \\
\text { adequate. }\end{array}$ & $\begin{array}{l}\text { The presentation } \\
\text { does not include } \\
\text { evidence of } \\
\text { organization. }\end{array}$ \\
\hline Preparation & & $\begin{array}{l}\text { Presentation } \\
\text { indicates detailed } \\
\text { preparation. }\end{array}$ & $\begin{array}{l}\text { Presentation } \\
\text { indicates adequate } \\
\text { preparation. }\end{array}$ & $\begin{array}{l}\text { Presentation indicates } \\
\text { minimal preparation. }\end{array}$ & $\begin{array}{l}\text { Presentation } \\
\text { indicates a lack of } \\
\text { preparation. }\end{array}$ & $\begin{array}{l}\text { Presentation } \\
\text { shows no } \\
\text { evidence of } \\
\text { preparation. }\end{array}$ \\
\hline Visual Aids & & $\begin{array}{l}\text { Visual aids are of } \\
\text { excellent quality, } \\
\text { easy to read, and } \\
\text { relevant to the } \\
\text { presentation. Visuals } \\
\text { of all required } \\
\text { elements are present. }\end{array}$ & $\begin{array}{l}\text { Visual aids are } \\
\text { adequate, easy to } \\
\text { read, and relevant to } \\
\text { the presentation. } \\
\text { Visuals of all required } \\
\text { elements are present. }\end{array}$ & $\begin{array}{l}\text { Visual aids are } \\
\text { somewhat effective } \\
\text { but may include } \\
\text { vocabulary or spelling } \\
\text { errors. Visuals of all } \\
\text { required elements are } \\
\text { present. }\end{array}$ & $\begin{array}{l}\text { Visual aids lack } \\
\text { effectiveness. Aids } \\
\text { may lack appropriate } \\
\text { content. Aids include } \\
\text { multiple vocabulary } \\
\text { or spelling errors. All } \\
\text { required elements } \\
\text { are not present. }\end{array}$ & $\begin{array}{l}\text { The presentation } \\
\text { shows no } \\
\text { evidence of visual } \\
\text { aids. }\end{array}$ \\
\hline
\end{tabular}

- focuses on quality of the presentation rather than specific pitch elements

- leverage text for delivery aspects 
Figure 4.10 Rubric 10

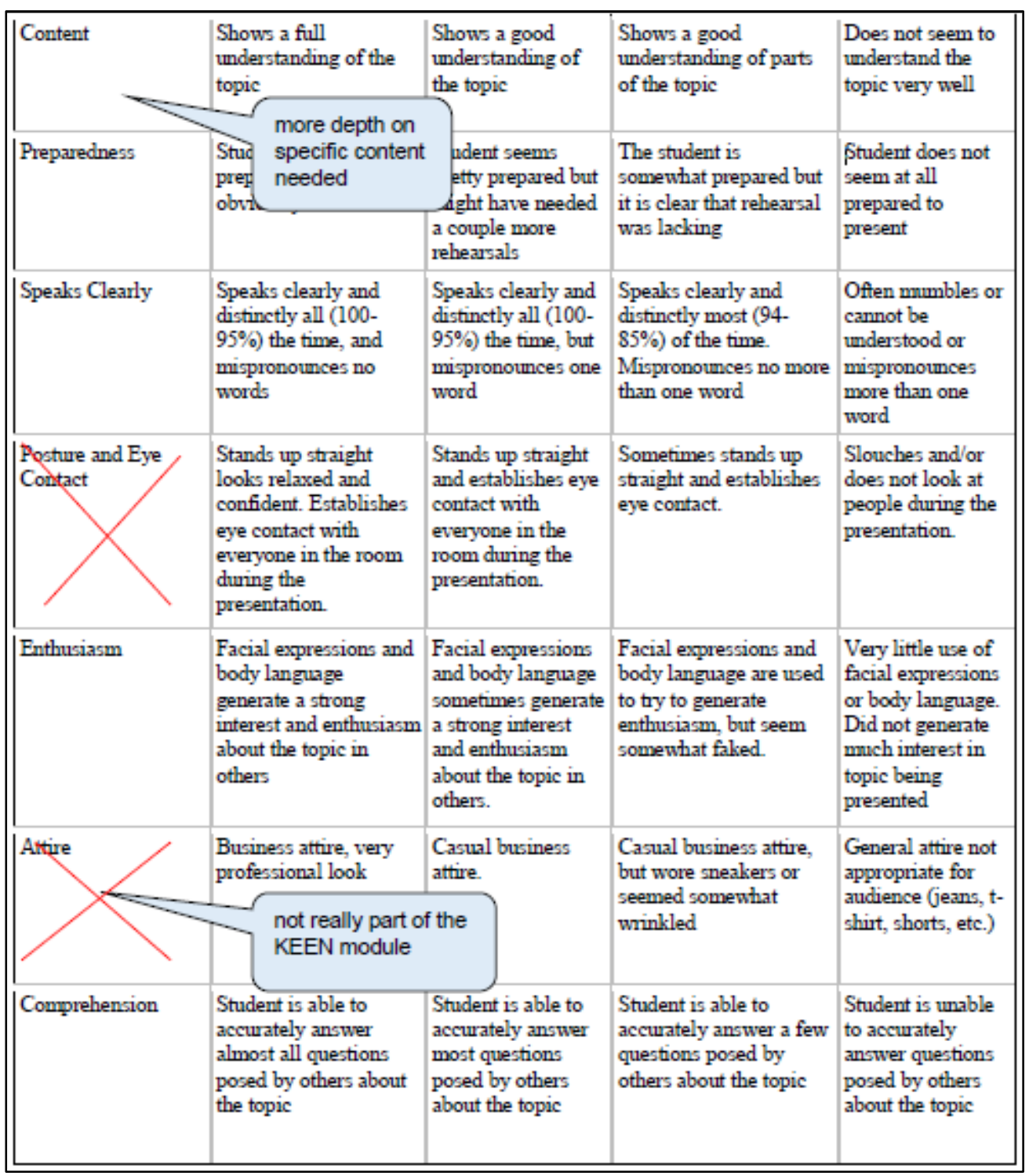

- focuses on quality of the presentation rather than specific pitch elements

- leverage appropriate text for delivery aspects 


\section{Figure 4.11 Rubric 11}

1. Was the student prepared and ready to deliver their pitch?

2. Did the student introduce themselves and clearly articulate what they intend to do with their degree?

3. Did the student demonstrate their passion for the industry?

4. Was the student's pitch well thought out and concise, holding your attention until the end?

5. Did the student come across as sincere, confident, and engaged?

6. Were the words or statements the student used interesting, different, and thought provoking as opposed to cliché?

7. Did the student clearly communicate how their interest and strengths would benefit a prospective employer?

8. Did the student end the pitch with a clear action statement?

9. Did the student maintain good posture and eye contact?

- more geared toward a live pitch to get a job 


\section{Figure 4.12 Rubric 12}

Oral Communication VALUE Rubric

for more information, please contact value@aack.org

Definition

Oral communication is a prepared, purposeful presentation designed to increase knowledge, to foster understanding, or to promote change in the listeners' attitudes, values, beliefs, or behaviors.

Evaluators are encouraged to assign a zero to any work sample or collection of work that does not meet benchmark (cell one) level performance.

\begin{tabular}{|c|c|c|c|c|}
\hline & $\begin{array}{c}\text { Capstone } \\
4\end{array}$ & Miles & stones & $\begin{array}{c}\text { Benchmark } \\
1\end{array}$ \\
\hline Organization & $\begin{array}{l}\text { Organizational pattern (specific } \\
\text { introduction and conclusion, sequenced } \\
\text { material within the body, and transitions) } \\
\text { is clearly and consistently observable and } \\
\text { is skillful and makes the content of the } \\
\text { presentation cohesive. }\end{array}$ & $\begin{array}{l}\text { Organizational pattern (specific } \\
\text { introductionand conclusion, sequenced } \\
\text { material within the body, and transitions) } \\
\text { is clearly and consistently observable } \\
\text { within the presentation. }\end{array}$ & $\begin{array}{l}\text { Organizational pattern (specific } \\
\text { introduction and conclusion, sequenced } \\
\text { material within the body, and transitions) } \\
\text { is intermittently observable within the } \\
\text { presentation. }\end{array}$ & $\begin{array}{l}\text { Organizational pattern (specific } \\
\text { introduction and conclusion, sequenced } \\
\text { material within the body, and transitions) } \\
\text { is not observable within the presentation. }\end{array}$ \\
\hline Language & $\begin{array}{l}\text { Language choices are imaginative, } \\
\text { memorable and compelling and enhance } \\
\text { the effectiveness of the presentation. } \\
\text { Language in presentation is appropriate to } \\
\text { audience. }\end{array}$ & $\begin{array}{l}\text { Language choices are thoughtful and } \\
\text { generally support the effectiveness of the } \\
\text { presentation. Language in presentation is } \\
\text { appropriate to audience. }\end{array}$ & $\begin{array}{l}\text { Language choices are mundane and } \\
\text { commonplace and partially support the } \\
\text { effectiveness of the presentation. } \\
\text { Language in presentation is appropriate to } \\
\text { audience. }\end{array}$ & $\begin{array}{l}\text { Language choices are unclear and } \\
\text { minimally support the effectiveness of the } \\
\text { presentation. Language in presentation is } \\
\text { not appropriate to audience. }\end{array}$ \\
\hline Delivery & $\begin{array}{l}\text { Delivery techniques (posture, gesture, eye } \\
\text { contact, and vocal expressiveness) make } \\
\text { the presentation compelling, and speaker } \\
\text { appears polished and confident. }\end{array}$ & $\begin{array}{l}\text { Delivery techniques (posture, gesture, eye } \\
\text { contact, and vocal expressiveness) make } \\
\text { the presentation interesting, and speaker } \\
\text { appears comfortable. }\end{array}$ & $\begin{array}{l}\text { Delivery techniques (posture, gesture, eye } \\
\text { contact, and vocal expressiveness) make } \\
\text { the presentation understandable, and } \\
\text { speaker appears tentative. }\end{array}$ & $\begin{array}{l}\text { Delivery techniques (posture, gesture, eye } \\
\text { contact, and vocal expressiveness) detract } \\
\text { from the understandability of the } \\
\text { presentation, and speaker appears } \\
\text { uncomfortable. }\end{array}$ \\
\hline Supporting Material & $\begin{array}{l}\text { A variety of types of supporting materials } \\
\text { (explanations, examples, illustrations, } \\
\text { statistics, analogies, quotations from } \\
\text { relevant authorities) make appropriate } \\
\text { reference to information or analysis which } \\
\text { significantly supports the presentation or } \\
\text { establishes the presenter's } \\
\text { credibility/authority on the topic. }\end{array}$ & $\begin{array}{l}\text { Supporting materials (explanations, } \\
\text { examples, illustrations, statistics, analogies, } \\
\text { quotations from relevant authorities) make } \\
\text { appropriate reference to information or } \\
\text { analysis which generally supports the } \\
\text { presentation or establishes the presenter's } \\
\text { credibility/authority on the topic. }\end{array}$ & \begin{tabular}{|l|} 
Supporting materials (explanations, \\
examples, illustrations, statistics, analogies, \\
quotations from relevant authorities) make \\
appropriate reference to information or \\
analysis which partially supports the \\
presentation or establishes the presenter's \\
credibility/authority on the topic.
\end{tabular} & $\begin{array}{l}\text { Insufficient supporting materials } \\
\text { (explanations, examples, illustrations, } \\
\text { statistics, analogies, quotations from } \\
\text { relevant authorities) make reference to } \\
\text { information or analysis which minimally } \\
\text { supports the presentation or establishes } \\
\text { the presenter's credibility/authority on the } \\
\text { topic. }\end{array}$ \\
\hline Central Message & $\begin{array}{l}\text { Central message is compelling (precisely } \\
\text { stated, appropriately repeated, memorable, } \\
\text { and strongly supported.) }\end{array}$ & $\begin{array}{l}\text { Central message is clear and consistent } \\
\text { with the supporting material. }\end{array}$ & $\begin{array}{l}\text { Central message is basically } \\
\text { understandable but is not often repeated } \\
\text { and is not memorable. }\end{array}$ & $\begin{array}{l}\text { Central message can be deduced, but is } \\
\text { not explicitly stated in the presentation. }\end{array}$ \\
\hline
\end{tabular}

- focuses on quality of the presentation rather than specific pitch elements

- high quality instrument widely used

\section{Our Proposed Elevator Pitch Rubric}

The rubric we synthesized from observations of the rubrics given in Section 4 is given in Figure 5.1. We had two goals for the presentation of the rubric: (1) the rubric should fit on one $81 / 2 \times 11$ inch piece of paper, and (2) the numeric scores should be determined by the persons applying the rubric in their courses. The scoring categories were inspired by the 4 categories used by the VALUE rubrics, although the descriptive words were altered (from "Capstone" to "Excellent," for example). The additional commentary on the right side of the rubric was intended to capture notes about how the pitch could be improved. The top half of the rubric focuses on content: hook/intro, goals for the solution, target audience, competitive advantage, and closing. The bottom category is for the presentation's delivery and it includes evaluation of clarity and impact. 
Figure 5.1 Elevator Pitch Rubric

\begin{tabular}{|c|c|c|}
\hline \multicolumn{3}{|l|}{ content } \\
\hline $\begin{array}{l}\text { hook/intro } \\
\text { The problem, need, or opportunity is } \\
\text { clearly explained and the significance is } \\
\text { evident; (video) the speakers' names and } \\
\text { faces are presented clearly. }\end{array}$ & $\begin{array}{l}\square \text { excellent } \\
\square \text { very good } \\
\square \text { acceptable } \\
\square \text { marginal }\end{array}$ & $\begin{array}{l}\text { needs improvement: } \\
\text { q problem/need/opportunity } \\
\square \text { speaker introduction } \\
\text { comments: }\end{array}$ \\
\hline $\begin{array}{l}\text { goals for solution } \\
\text { A detailed explanation of the proposed } \\
\text { solution and a convincing statement of } \\
\text { how it provides value for the customer } \\
\text { are given. }\end{array}$ & $\begin{array}{l}\square \text { excellent } \\
\square \text { very good } \\
\square \text { acceptable } \\
\square \text { marginal }\end{array}$ & $\begin{array}{l}\text { needs improvement: } \\
\square \text { solution } \\
\text { q value proposition } \\
\text { comments: }\end{array}$ \\
\hline $\begin{array}{l}\text { target audience } \\
\text { The intended audience is well } \\
\text { defined/identified and the market or user } \\
\text { base is quantified. }\end{array}$ & $\begin{array}{l}\square \text { excellent } \\
\square \text { very good } \\
\square \text { acceptable } \\
\square \text { marginal }\end{array}$ & $\begin{array}{l}\text { needs improvement: } \\
\square \text { target audience } \\
\square \text { size } \\
\text { comments: }\end{array}$ \\
\hline $\begin{array}{l}\text { competitive advantage } \\
\text { Understanding of the competition and } \\
\text { shortcomings are highlighted; credibility } \\
\text { of the proposed solution and } \\
\text { qualifications of the team indicate strong } \\
\text { potential for success. }\end{array}$ & $\begin{array}{l}\square \text { excellent } \\
\square \text { very good } \\
\square \text { acceptable } \\
\square \text { marginal }\end{array}$ & $\begin{array}{l}\text { needs improvement: } \\
\square \text { competition } \\
\square \text { advantage } \\
\text { comments: }\end{array}$ \\
\hline $\begin{array}{l}\text { closing } \\
\text { Cost of building a prototype and retail } \\
\text { cost are anticipated and justified; the } \\
\text { conclusion highlights benefits and } \\
\text { potential for profit. }\end{array}$ & $\begin{array}{l}\square \text { excellent } \\
\square \text { very good } \\
\square \text { acceptable } \\
\square \text { marginal }\end{array}$ & $\begin{array}{l}\text { needs improvement: } \\
\square \text { costs } \\
\text { c conclusion } \\
\text { comments: }\end{array}$ \\
\hline \multicolumn{3}{|l|}{ delivery } \\
\hline $\begin{array}{l}\text { clarity } \\
\text { Speakers are polished and delivery } \\
\text { techniques make the presentation } \\
\text { understandable and engaging. }\end{array}$ & $\begin{array}{l}\square \text { excellent } \\
\square \text { very good } \\
\square \text { acceptable } \\
\square \text { marginal }\end{array}$ & $\begin{array}{l}\text { needs improvement: } \\
\text { q organization/length } \\
\text { g grammar/pronunciation } \\
\square \text { visual aids } \\
\text { comments: }\end{array}$ \\
\hline $\begin{array}{l}\text { impact } \\
\text { The presentation inspires and holds } \\
\text { attention; the pitch is persuasive and } \\
\text { informative. }\end{array}$ & $\begin{array}{l}\square \text { excellent } \\
\square \text { very good } \\
\square \text { acceptable } \\
\square \text { marginal }\end{array}$ & $\begin{array}{l}\text { needs improvement: } \\
\square \text { enthusiasm } \\
\square \text { creativity } \\
\square \text { compelling story } \\
\square \text { team participation } \\
\text { comments: }\end{array}$ \\
\hline
\end{tabular}




\section{Assessment and Conclusions}

The rubric was employed for assessing elevator pitches for 20 senior design team projects. All of the students completed the KEEN elevator pitch module and participated in the in-class activities. The rubric was available to the students prior to starting the assignment. Using the point scoring system outlined in Table 6.1, grades were assigned based on the rubric. Table 6.2 provides a statistical summary of the grades assigned in the first offering of the KEEN module in our senior design course along with the first use of the rubric proposed in Section 5. The percentage row is what percent of the total points for the category is represented by the average score for that category. Overall, the scores were very good (most of the minimum scores belong to the same project.)

Table 6.1 Point Values Assigned to Categories

\begin{tabular}{|l|r|r|r|r|}
\hline \multicolumn{1}{|c|}{ category } & excellent & very good & acceptable & marginal \\
\hline hook/intro & $19-20$ & $17-18$ & $14-16$ & $\leq 13$ \\
\hline goals for solution & $19-20$ & $17-18$ & $14-16$ & $\leq 13$ \\
\hline target audience & 10 & $8-9$ & $6-7$ & $\leq 5$ \\
\hline competitive advantage & $19-20$ & $17-18$ & $14-16$ & $\leq 13$ \\
\hline closing & 10 & $8-9$ & $6-7$ & $\leq 5$ \\
\hline clarity & 10 & $8-9$ & $6-7$ & $\leq 5$ \\
\hline impact & 10 & $8-9$ & $6-7$ & $\leq 5$ \\
\hline
\end{tabular}

Table 6.2 Summary of Scoring $(n=20)$

\begin{tabular}{|l|r|r|r|r|r|r|r|r|}
\hline & \multicolumn{1}{l|}{ total } & \multicolumn{1}{l|}{ intro } & \multicolumn{1}{l|}{ goals } & \multicolumn{1}{l|}{ audience } & \multicolumn{1}{l|}{ advantage } & \multicolumn{1}{l|}{ closing } & \multicolumn{1}{l|}{ clarity } & impact \\
\hline min & 60 & 18 & 12 & 8 & 4 & 2 & 8 & 4 \\
\hline max & 100 & 20 & 20 & 10 & 20 & 10 & 10 & 10 \\
\hline median & 92 & 20 & 20 & 10 & 18 & 9 & 9.5 & 9.5 \\
\hline average & 90.65 & 19.20 & 17.80 & 9.50 & 17.65 & 8.45 & 9.25 & 8.80 \\
\hline st-dev & 9.21 & 1.01 & 2.82 & 0.76 & 3.48 & 2.09 & 0.85 & 1.61 \\
\hline percentage & & $96.00 \%$ & $89.00 \%$ & $95.00 \%$ & $88.25 \%$ & $84.50 \%$ & $92.50 \%$ & $88.00 \%$ \\
\hline
\end{tabular}

For the lowest scoring (marginal to acceptable) projects in the four lowest scoring categories, we examine the reasons for the assigned score. The description of the category is repeated here, along with the main criteria for scoring; selected comments from the professor evaluating the pitch are provided.

\section{1. goals for solution}

A detailed explanation of the proposed solution and a convincing statement of how it provides value for the customer are given. 
$\square$ solution

$\square$ value proposition

For teams that scored in the marginal (2) and acceptable (6) ranges, here are selected comments regarding their goals and value propositions:

- what is your product? (you never actually describe it)

- does not contain a detailed explanation of the solution and how it provides value

- insufficient detail about the proposed solution

- it's not clear how the project will [achieve its stated goals]

Only one of the teams had a shortcoming in the value proposition; all of the lower scores for this category were due to inadequate descriptions of the solution.

\section{2. competitive advantage}

Understanding of the competition and shortcomings are highlighted; credibility of the proposed solution and qualifications of the team indicate strong potential for success.

$\square$ competition

$\square$ advantage

For teams that scored in the marginal (1) and acceptable (3) ranges, here are selected comments regarding their competitive advantage:

- does not identify competition, credibility of proposed solution, or qualifications of the team

- $\quad$ no mention of team qualifications

- insufficient comparison to competing solutions

- the advantage of the specific chosen solution is not clear other than that it's for [topic]

Most teams did well in this category, and even the acceptable ones only needed some additional details. The marginal score, however, was really poor because the team appeared to ignore this aspect of the assignment.

\section{3. closing}

Cost of building a prototype and retail cost are anticipated and justified; the conclusion highlights benefits and potential for profit.

$\square$ costs

$\square$ conclusion 
Only two teams were in the marginal category and one was in the acceptable category. The marginal closing neglected both the cost and the potential for profit, while the acceptable teams missed highlighting the benefits in the conclusion.

- $\quad$ cost of the project is not justified, nor is the potential for profit

- doesn't highlight benefits in conclusion

\section{4. impact}

The presentation inspires and holds attention; the pitch is persuasive and informative.

$$
\begin{aligned}
& \text { enthusiasm } \\
& \text { creativity } \\
& \text { compelling story } \\
& \text { team participation }
\end{aligned}
$$

One team scored in the marginal category and one scored in the acceptable category. The areas for improvement were identified as:

- no visual aids; pitch is not very informative (little actual information content)

- lacking in visual aids and the speakers/story could be more compelling and creative

Our intention in investigating the lower performing categories was to use the rubric as a diagnostic instrument. We thought it might be used to guide an instructor's focus the next time the course is offered or on a subsequent revision to the assignment by the current class. What we observed is that some teams apparently ignored the rubric and focused on only some aspects of the assignment; thus they scored poorly in most of the categories.

Two ideas that would reinforce the elevator pitch learning outcomes and might improve student achievement in the future are

1. go over the rubric in class and provide examples, and

2. have the students use the rubric to score good and bad pitches provided in the KEEN elevator pitch module.

In conclusion, we believe that the KEEN elevator pitch module is a valuable educational resource that can be leveraged in a variety of engineering courses at all levels in the undergraduate (and perhaps even graduate) curricula. The rubric provided here can help the students to understand the expectations for their assignment and can be used by professors to assist in grading and improving pedagogy.

\section{Related Work}

Duval-Couetil [6] provides an overview of entrepreneurship assessment practices targeted to faculty and program administrators. Shartrand et al. [11] assess the impact of technology entrepreneurship courses and programs on student learning by measuring prior and subsequent 
knowledge of terms, concepts, and entrepreneurial thinking. Their studies indicate that professional competency can be increased by curricular experiences. Other researchers propose and study entrepreneurship for engineering/computing students that include writing and pitching business plans, but none include a rubric for evaluating a pitch $[4,5,7,8,10,12]$.

Klein and Yoder [9] provide rubrics associated with entrepreneurial learning outcomes. The rubric for the KEEN learning outcome "Construct and effectively communicate a customerappropriate value proposition" overlaps with categories in our rubric (hook/intro and competitive advantage), but is 3 pages long and is missing the categories of clarity, impact, and qualifications of the team. The ONU General Education Outcome for "Effective Communication of a Customer-appropriate value proposition" has two categories related to oral communication: (1) overall organization of presentation, and (2) argument and rhetoric. It is too general for our purposes (not targeted to an elevator pitch specifically.)

\section{Acknowledgements}

Developers of "The Elevator Pitch - Advocating for Your Good Ideas" module are Edmond Dougherty, Director of Engineering Entrepreneurship, Villanova University, Julia Williams Executive Director Office of Institutional Research, Planning and Assessment \& Professor of English, Rose-Hulman Institute of Technology, and Ella Ingram, Associate Professor of Biology and Director of the Center for the Practice and Scholarship of Education, Rose-Hulman Institute of Technology.

Support for training, deployment, and assessment of the module was provided as a KEEN minigrant to the University of Cincinnati faculty.

\section{References}

[1] Byers, T., Seelig, T., Sheppard, S. and P. Weilerstein, P., "Entrepreneurship: Its Role in Engineering Education," The Bridge, Vol. 43, No. 2, 2013, pp.35-40.

[2] University of New Haven, "KEEN: Fostering an entrepreneurial mindset through integrated e-learning modules," http://www.newhaven.edu/engineering/kern-entrepreneurialengineering-network/elearning-modules/, accessed 2/9/2017.

[3] Prestero, T., "Design for People, Not Awards," TED talk, Boston, 2012, https://www.ted.com/talks/timothy_prestero_design_for_people_not_awards, accessed 2/9/2017.

[4] Binder, P., and J. Knauder, "Entrepreneurship in Engineering Education," International Conference on Interactive Collaborative Learning, Springer, 2016, pp. 399-404.

[5] Doboli, S., Kamberova, G.L., Impagliazzo, J., Fu, X., and E.H. Currie, “A Model of Entrepreneurship Education for Computer Science and Computer Engineering Students," IEEE Frontiers in Education Conference (FIE), Washington, D.C., USA, October 27-30, 2010. 
[6] Duval-Couetil, N., "Assessing the Impact of Entrepreneurship Education Programs: Challenges and Approaches," Journal of Small Business Management, Vol. 51, No. 3, 2013, pp. 394-409.

[7] Hallam, C.R.A, Leffel, A., and D. Womack, "Influencing Entrepreneurial Intent for New Technology Intrapreneurs and Entrepreneurs in a University Environment," Portland International Conference on Management of Engineering \& Technology, IEEE, Cape Town, South Africa, July 27-31, 2008, pp. 754-763.

[8] Höller, H., and S. Vorbach, "Entrepreneurship in Engineering Education: Graz University of Technology as a Case Study," International Conference on Interactive Collaborative Learning, Springer, 2016. pp. 486-499.

[9] Kleine, R.E., and J.D. Yoder, "Operationalizing and Assessing the Entrepreneurial Mindset: A Rubric Based Approach," The Journal of Engineering Entrepreneurship, Vol. 2, No. 2, 2011, pp. 57-86.

[10] Luryi, S., Tang, W., Lifshitz, N., Wolf, G., Doboli, S., Betz, J.A., Maritato, P., and Y. Shamash, "Entrepreneurship in Engineering Education," Frontiers in Education Conference-Global Engineering: Knowledge without Borders, Opportunities without Passports (FIE), Milwaukee, WI, USA, October 10-13, 2007.

[11] Shartrand, A., Weilerstein, P., Besterfield-Sacre, M., and B.M. Olds, "Assessing Student Learning in Technology Entrepreneurship," Frontiers in Education Conference (FIE), Saratoga Springs, NY, USA, October 22-25, 2008.

[12] Zidek, L., "Engineering Service Learning, Engineering Entrepreneurship and Assessment: Building a Program that Works," Frontiers in Education Conference (FIE), Washington, D.C., USA, October 27-30, 2010. 